\title{
Thermoeconomic Optimisation of Steam Condenser for Combined Cycle Power Plant
}

\author{
Muammer Alus \\ Faculty of Engineering \\ Mechanical and Industrial \\ Engineering Department \\ University of Elmergib \\ Alkhoms, Libya
}

\author{
Mohamed Elrawemi \\ Faculty of Engineering \\ Mechanical and Industrial \\ Engineering Department \\ University of Elmergib \\ Alkhoms, Libya
}

\author{
Faraj Eldabee \\ Faculty of Engineering, \\ Mechanical and Industrial \\ Engineering Department \\ University of Elmergib \\ Alkhoms, Libya
}

\begin{abstract}
In this study, the effect of condenser pressure on condenser area and the thermoeconomic parameters is investigated. The objective function of the thermoeconomic optimisation is to minimise the production costs per unit of electrical output and to maximise the annual cash flow of the power plant. Therefore, the thermoeconmic parameters are generated for different range of condenser pressure. The case 283 MW combined cycle gas turbine (CCGT) power plant with typical design of commercial combined cycle power plant was demonstrated as an example. The optimised combined cycle was compared with a regular CCGT plant. The results indicated that the thermoeconomic optimisation procedure used in this study led to a significant improvement for the economic parameters, where the annual cash flow was increased by $1.1 \mathrm{M} \$$, and the production cost of electricity was decreased by 0.043 centdollar per kilowatt-hour.
\end{abstract}

Keywords: thermoeconomic; optimisation; steam; condenser; combined cycle gas turbine (CCGT)

\section{INTRODUCTION}

The condenser is a heat transfer device or unit used to condense a substance from its gaseous state to its liquid state, typically by cooling it. The main use of the condenser is to receive the exhaust steam from steam turbine and condense it. The benefit of this process is the energy, which can be utilised instead of exhausting it to the atmosphere. The steam condenser generally condenses the steam to a pressure below atmospheric. This allows the turbine to generate more work. The condenser also converts discharge steam back to feed water, which is returned to steam generators. In the condenser, the latent heat of condensation is conducted to the medium flowing through the cooling tubes. The thermal power plants are designed based on required conditions, however actually the inlet conditions are not as per the designed conditions. In practical situations, once the power plants are installed there are a lot of constrains. This tends to reduce or increase the output power and heat rate of thermal power plants. As a result of these conditions, the designed power and heat rate are never achieved [1].

Moreover, the designed features of the condenser have a significant impact, but it is expansive to replace them when the plant is operating. At present, it is possible to improve the design for new plant due to technology development. The considerations that the designers should take into account are the weather condition (cooling water temperature) and the economic condition (fuel price), where the power plant is installed.

Different approaches can be found in the literature regarding the performance of steam condenser. The impact of cooling water temperature on the efficiency of the power plant was stated using simulator based on IAPWS-IF97. It is found that increasing the pressure in the condenser to $1 \mathrm{kPa}$ decreases the efficiency between 1.0 to $1.5 \%$ [3]. Also, the parameters, which affect the performance of the condenser and the power plant, were studied. The authors found that the performance of the condenser was varied due to the cooling water inlet temperature, flow rate of cooling water and pressure in energy [4]. Furthermore, an optimisation of a condenser in a thermal power plant was performed. The effects of the condenser pressure on the condenser area and the initial cost of the condenser was investigated. It is concluded that the area of condenser increases when the pressure of condenser decreases, accordingly the initial cost of the condenser increases [5].

The earlier studies revealed that the condenser pressure has an influence on the energy efficiency of the thermal power plants and on the area of the condenser. These aspects have prompted the authors of this research paper to focus on studying the effect of the condenser pressure on the thermoeconomic parameters.

\section{THERMODYNAMIC OPTIMISATION MODEL}

The objective of thermodynamic optimisation is to enhance the efficiency of the combined cycle power plan (CCGT) and to maximise the electrical power in the steam cycle (steam turbine gross power). Here, a CCGT cycle with triple-pressure HRSG will be considered. Figure 1 shows a schematic diagram of a CCGT. The compute code to calculate the heat balance of triple-pressure HRSG of CCGT was developed using FORTRAN 90. The water-steam properties were derived from the standard IAPWS-IF97. The properties of the gas turbine exhaust gases, which are combustion products of the specified fuel, were calculated according to [6]. The assumptions and the studied parameters, which are selected for the thermodynamic analysis of the plant, are presented in Table 1. 


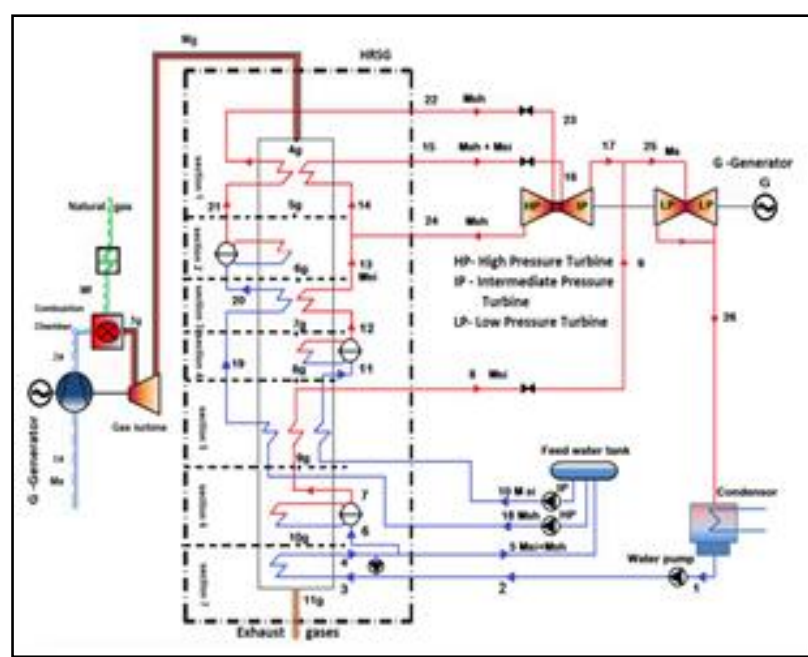

Figure1. Gas turbine and steam turbine combined cycle - heat balance diagram [1]

Table 1- Gas turbine parameters for CCGT with the triplepressure HRSG [1]

\begin{tabular}{|c|c|}
\hline Parameter & Value \\
\hline \multicolumn{2}{|l|}{ 1. Gas Turbine Cycle (Alstom GT24/1994) } \\
\hline $\begin{array}{l}\text { Ambient air pressure [bar] \& ambient air } \\
\text { temperature }[\mathrm{oC}]\end{array}$ & $\begin{array}{l}1.013 \\
\& 15\end{array}$ \\
\hline Electrical power at the generator output [MW] & 187.7 \\
\hline Exhaust gas mass flow $[\mathrm{kg} / \mathrm{s}]$ & 445 \\
\hline $\begin{array}{l}\text { Exhaust gas temperature at the gas turbine outlet } \\
{[\mathrm{oC}]}\end{array}$ & 612 \\
\hline The gas turbine efficiency [\%] & 36.9 \\
\hline Lower heat value of the fuel $[\mathrm{kJ} / \mathrm{kg}]$ & 47141 \\
\hline \multicolumn{2}{|l|}{ 2. Steam Turbine Cycle } \\
\hline $\begin{array}{l}\text { The pinch point temperature difference for HP, IP } \\
\text { and LP }[\mathrm{oC}]\end{array}$ & 13 \\
\hline $\begin{array}{l}\text { The minimum temperature difference between the } \\
\text { gas turbine exhaust gases and live/reheat steam } \\
{\left[{ }^{\circ} \mathrm{C}\right]}\end{array}$ & 25 \\
\hline Live steam pressure (HP) [bar] & 104 \\
\hline $\begin{array}{l}\text { Live steam temperature at the inlet of the HP steam } \\
\text { turbine }[\mathrm{oC}]\end{array}$ & 545 \\
\hline Pressure of reheat steam (IP steam turbine) [bar] & 36 \\
\hline $\begin{array}{l}\text { Temperature of the reheat steam (IP steam turbine) } \\
{[\mathrm{oC}]}\end{array}$ & 545 \\
\hline Pressure of the inlet LP steam turbine [bar] & 5 \\
\hline Temperature of the superheated steam at $8[\mathrm{oC}]$ & 235 \\
\hline Temperature of the superheated steam at $13[\mathrm{oC}]$ & 320 \\
\hline Steam mass flow $[\mathrm{kg} / \mathrm{s}]$ & 73 \\
\hline $\begin{array}{l}\text { Low-pressure steam turbine outlet (condenser } \\
\text { pressure) [bar] }\end{array}$ & 0.057 \\
\hline Feed water temperature at $3[\mathrm{oC}]$ & 60 \\
\hline \multicolumn{2}{|l|}{ 3. Combined Cycle Power Plant } \\
\hline Net total electrical power (MW) & 283.07 \\
\hline Net plant efficiency $(\%)$ & 55.65 \\
\hline \multicolumn{2}{|l|}{ 4. Assumption } \\
\hline $\begin{array}{l}\text { The isentropic efficiency of all three steam turbine } \\
\text { parts [\%] }\end{array}$ & 90 \\
\hline The isentropic efficiencies of water pumps [\%] & 82 \\
\hline The mechanical efficiency [\%] & 99.5 \\
\hline The generator efficiency [\%] & 98 \\
\hline The heat recovery steam generator efficiency & 99.3 \\
\hline $\begin{array}{l}\text { The pressure drops for water in the economisers } \\
{[\%]}\end{array}$ & 25 \\
\hline
\end{tabular}

\begin{tabular}{|c|c|}
\hline $\begin{array}{l}\text { The pressure drops for steam in the reheat and } \\
\text { super-heater tubes [\%] }\end{array}$ & 8 \\
\hline $\begin{array}{l}\text { The overall heat transfer coefficients for sections of } \\
\text { the HRSG }\left[\mathrm{W} / \mathrm{m}^{2} \mathrm{~K}\right] \\
\text { - economiser } \\
\text { - evaporator } \\
\text { - } \quad \text { super-heater and reheat }\end{array}$ & $\begin{array}{l}42.6 \\
43.7 \\
50.0 \\
\end{array}$ \\
\hline $\begin{array}{l}\text { The overall heat transfer coefficient for the } \\
\text { condenser }\left[\mathrm{Wm}^{-2} \mathrm{~K}^{-1}\right]\end{array}$ & 2500 \\
\hline $\begin{array}{l}\text { The inlet cooling water temperature in condenser } \\
\left({ }^{\circ} \mathrm{C}\right)\end{array}$ & 20 \\
\hline
\end{tabular}

\subsection{The Condenser Model}

In power plants, the most commonly used condenser is the steam surface condenser. Consequently, steam surface condenser with open cycle cooling water supply system in this study is assumed.

\subsubsection{Element of Surface Condenser}

The heat mechanism is the condensation of saturated steam outside the tubes and heating of the circulating water inside the tubes. Figure 2 presents the heat transfer diagram of the condenser. The steam temperature $\left(t_{s}\right)$ is the saturation temperature at the condenser pressure. The difference between the steam temperature $\left(t_{s}\right)$ and the water inlet temperature $\left(t w_{1}\right)$ is defined as the initial temperature difference (ITD). The difference between the steam temperature $\left(t_{s}\right)$ and the water outlet temperature $\left(t w_{2}\right)$ is known as the terminal temperature difference (TTD). The circulating water inlet temperature should be sufficiently lower than the steam saturation temperature to result reasonable values of TTD.

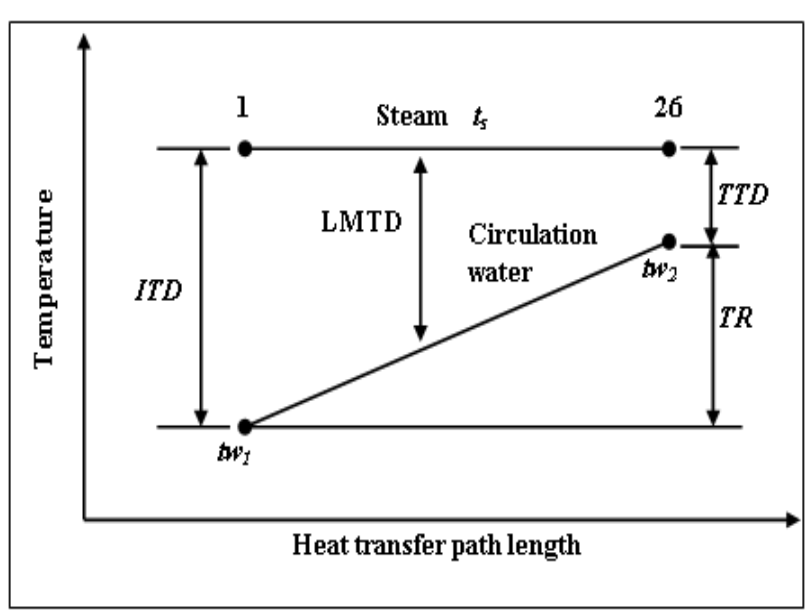

Figure 2. Heat transfer diagram of condenser

\subsubsection{Calculation of Condenser Heat Transfer Area}

The heat transfer rate between the cooling water and the steam vapour is the key parameter of the thermal analysis of the steam condenser. The heat from the exit steam is:

$\dot{Q}_{S T}=\dot{m}_{S T}\left(h_{26}-h_{1}\right)$

The heat that cooling water gets:

$$
\dot{Q}_{w}=\dot{m}_{w} c p_{w}\left(t w_{2}-t w_{1}\right)
$$

where $\dot{m}_{w}$ represents the cooling water flow rate in $(\mathrm{kg} / \mathrm{s})$, and $c p_{w}$ the specific heat of the water in (kJ/kg.K).

The heat transferring in condenser is:

$$
\dot{Q}_{\text {Cond. }}=A_{\text {Cond. }} \cdot U_{\text {Cond. }} \cdot L M T D_{\text {Cond }} \text {. }
$$


where, $\dot{Q}_{\text {Cond }}$ is the heat transferred and $U_{\text {Cond. }}$. is the heat transfer coefficient for the condenser in $\left(\mathrm{W} / \mathrm{m}^{2} . \mathrm{K}\right)$.

In condenser calculation, the heat transfer coefficient UCond. is assumed. LMTD Cond is the logarithmic mean temperature difference for the condenser, which is defined as:

$$
L M T D_{\text {Cond. }}=\frac{T R}{\ln \frac{1}{1-\frac{T R}{I T D}}}
$$

where $T R$ is the temperature rise in the condenser and defined as $\left(t_{w 2}-t_{w 1}\right)$ and ITD is the initial temperature difference.

The condenser heat transfer area $A_{\text {Cond. }}$ was calculated according to [7]:

$$
A_{\text {Cond. }}=\frac{\dot{Q}_{\text {Cond }}}{U_{\text {Cond. }} \cdot L M T D_{\text {Cond. }}}=\frac{\dot{m}_{S T}\left(h_{C}-h_{1}\right)}{U_{\text {Cond. }} \cdot L M T D_{\text {Cond. }}}=\frac{\dot{m}_{w} c p_{w}\left(t w_{2}-t w_{1}\right)}{U_{\text {Cond. }} \cdot L M T D_{\text {Cond. }}}
$$

\subsection{Combined Cycle Efficiency}

The overall cycle efficiency can be obtained from the steam power and gas turbine powers, which also are dependent on many other variables, such as condenser pressure, steam pressures and ambient temperature. The thermal efficiency in a combined cycle plant is defined by the relation:

$$
\eta_{C C G T}=\frac{W_{C C G T}}{Q_{\text {add }}}=\frac{W_{S T}\left(\dot{m}_{S T}, h_{c o n d}, \eta_{S T}\right)+W_{G T}}{\dot{m}_{f} \cdot H_{l}}
$$

where $\dot{m}_{f}$ is mass flow rate of fuel in $(\mathrm{kg} / \mathrm{s}), H_{l}$ Lower heat value of the fuel $(\mathrm{kJ} / \mathrm{kg})$.

\section{THERMOECONOMIC OPTIMISATION MODEL}

To perform the thermoeconmic optimisation, some economic parameters should be assumed, and relations between the thermodynamic parameters and capital cost have to be established and objective functions defined.

\subsection{Main Thermoeconomic \\ Characteristics of CCGTs}

The thermoeconomic optimisation was performed under the following conditions, which were taken according to [1]:

- $\quad$ The average life of the combined cycle power plant is 20 years.

- The power plant is operated for $7500 \mathrm{~h}$ a year.

- The unit selling price of generated electricity is 0.114 $\$ / \mathrm{kWh}$.

- $\quad$ Price of natural gas $0.0467 \$ / \mathrm{kWh}$.

- The installed costs of the economiser, evaporator, superheater and reheat sections of the HRSG are 45.7, 34.8 and $96.2 \$ / \mathrm{m}^{2}$, respectively.

\subsection{Functions of Component Capital Costs}

The basic problem in the analysis of the economic effectiveness of investments in energy systems is the determination of capital costs. For this study, the cost functions for the major components of a combined cycle power plants were taken from literature: cost of gas turbine $C_{G T}$ [8], cost of HRSG $C_{H R S G}$ [9], cost of steam turbine $C_{S T}$, cost of pump $C_{\text {Pump }}$ and cost of generator

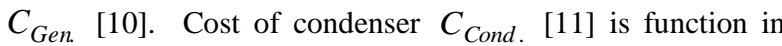
condenser area and is expressed as:

$$
C_{\text {Cond }}=280 . A_{\text {Cond }}^{1.01}
$$

The cost functions give net capital costs of the components. However, the net capital cost does not include: transport and assembly costs, supervising, accessories, engineering and project management, commissioning and other connected costs. Therefore, the additional correction factor $R$ was introduced in Eq. 8 to cover these additional costs and increase in price in recent period. The $R$ value is obtained by analysis and consulting the market. In the calculations, the value of $R$ is assumed to be 3.0 [1].

The total capital costs (investment costs) of a combined cycle power plants are given by:

$$
C_{C C G T}=R \cdot \sum C=R \cdot\left(C_{G T}+C_{H R S G}+C_{S T}+C_{C o n d}+C_{P_{u m p}}+C_{G e n}\right)
$$

The cost function of HRSG, steam turbine, condenser, pump and generator in Eq. 8 is expressed as function of operating parameters ( $\left.p_{\text {Live Steam }}, t_{\text {Live Steam }}, p_{\text {Cond. }}, e t c\right)$. Therefore, any change in these variables will cause a change in the total capital costs.

\subsection{Objective Function}

The annual cash flow $(B)$ and the production cost of electricity $\left(C_{k W h}\right)$ have been chosen as an objective function of the thermeconomic optimisation.

The annual cash flow $(B)$ is the difference between the annual total income $\left(I_{t o t}\right)$ and the total cost per year $\left(C_{t o t}\right)$ as pointed out by [12], [13]:

$$
B=I_{t o t}-C_{t o t}
$$

The production cost of electricity was defined as pointed out by [12], [13]:

$$
C_{\mathrm{kWh}}=\frac{C_{\mathrm{tot}}}{W_{C C G T} \cdot h}
$$

Where $C_{\text {tot }}$ the total cost per year and the product $\left(W_{C C G T} \cdot h\right)$ is the total annual energy production.

The annual cash flow $(B)$ is the difference between the annual total income $\left(I_{t o t}\right)$ and the total cost per year $\left(C_{t o t}\right)$ as pointed out by [12], [13]:

$$
B=I_{t o t}-C_{t o t}
$$

The annual total income can be calculated using

$$
I_{\text {tot }}=S \cdot W_{C C G T} \cdot h
$$

where $S$ is the selling price per unit of electricity.

The total cost per year includes the total annual fuel cost, the amortisation cost and the operating and maintenance cost, as shown in the following equation:

$$
C_{t o t}=C_{T F}+C_{a}+C_{o \& m}
$$

The total annual fuel cost $\left(C_{T F}\right)$ is defined as follows: 


$$
C_{T F}=c_{f} \cdot\left(\frac{W_{C C G T}}{\eta_{C C G T}}\right) \cdot h
$$

The amortisation cost $\left(C_{a}\right)$ is summarised as pointed out by [13]:

$$
C_{a}=\frac{C_{C C G T}}{N}
$$

The operating and maintenance cost $\left(C_{o \& m}\right)$ is assumed to be $10 \%$ of the total plant cost as pointed out by [13]:

$$
C_{\text {o\&m }}=0.10 \cdot\left(C_{\text {tot }}\right)
$$

\section{RESULTS AND DISCUSSION}

The condenser pressure ( $P_{\text {Cond. }}$ ) was in the range of 0.04 to 0.08 bar by adding 0.0005 bar incrementally in each step. The thermodynamic and the thermoeconomic parameters were calculated for each step.

Figure 3 shows the combined cycle gross power as a function of condenser pressure ( $P_{\text {Cond. }}$ ) of triple-pressure HRSG CCGTs. The result shows that the combined cycle gross power decreases by increasing $P_{\text {Cond. }}$. Decreasing the $P_{\text {Cond }}$. will lead to higher power output for the same mass flow rate and fuel input into gas turbine unit, resulting in higher work output of the steam turbine.

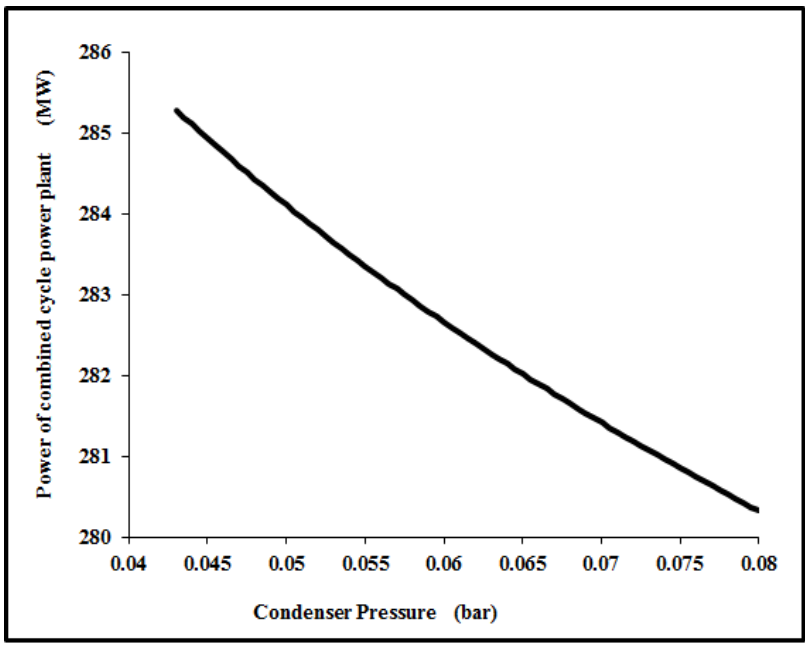

Figure 3. Effect of condenser pressure variations on the combined cycle gross power

Figure 4 shows the cost of condenser ( $C_{C o n d}$.) as a function on the condenser pressure ( $P_{C o n d}$.). Through the figure 4 , the result shows that a decrease in the $P_{\text {Cond. will significantly }}$ increase the necessary heat transfer surface area of condenser ( $A_{\text {Cond.. }}$ ) and incase the initial cost of condenser ( $C_{\text {Cond. }}$.). On the other hand, an increase in the area of the condenser means more the heat recovered and an improvement in the CCGT thermal efficiency.

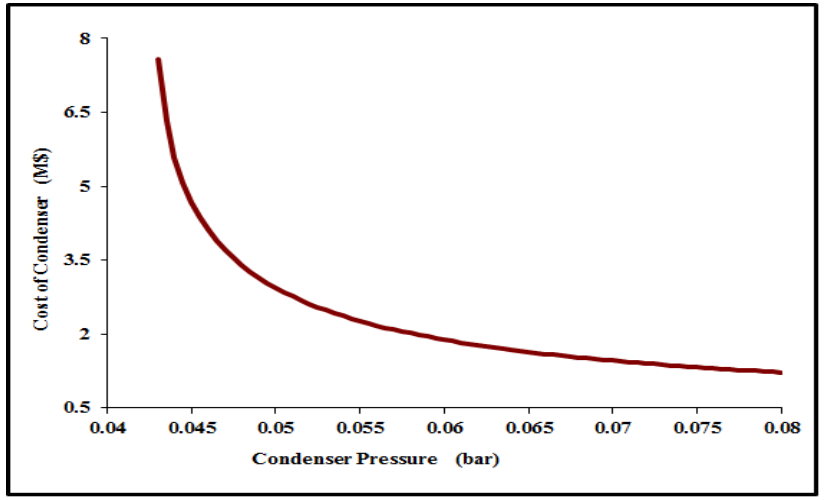

Figure 4. Effect of condenser pressure variations on the cost of condenser

Figure 5 demonstrates the effect of the condenser pressure ( $P_{\text {Cond. }}$ ) on the annual cash flow (B), which is defined by Eq. 9. As can be seen, annual cash flow (B) increases with increase in the $P_{\text {Cond. }}$, until it reaches the optimal value and then decreases with further increase in the $P_{\text {Cond. }}$. The result shows that the optimal value for the $P_{\text {Cond. }}$, at which the maximum annual cash flow (B) is achieved, is 0.0445 bar.

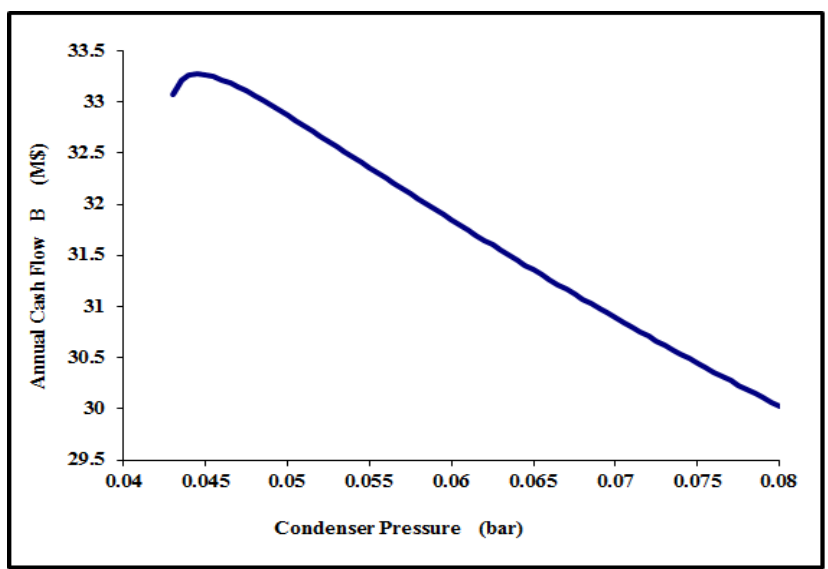

Figure 5. Effect of condenser pressure variations on the annual cash flow

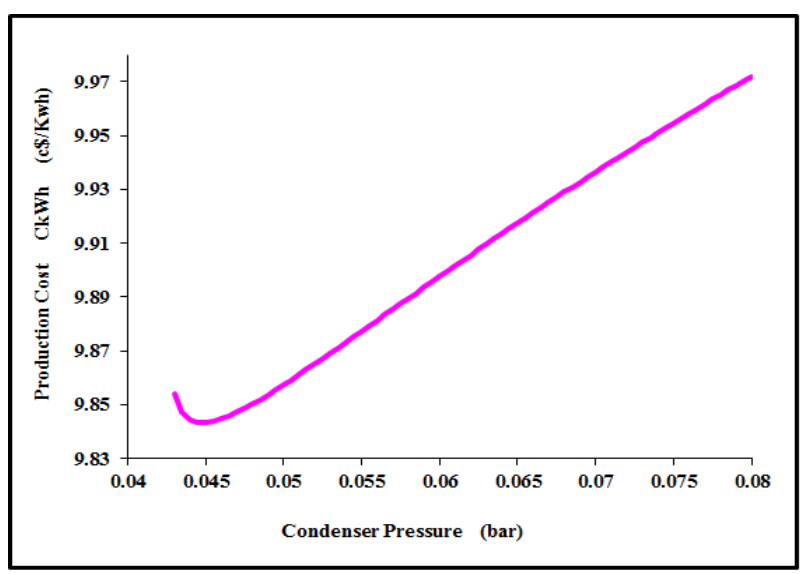

Figure 6. Effect of condenser pressure variations on the production cost of electricity 
Figure 6 illustrates the effect of the condenser pressure ( ) on the production cost of electricity, which is defined by Eq. 10 for a CCGTs with a triple-pressure HRSG. As seen from that, production cost of electricity decreases with an increase in the $P_{\text {Cond }}$, until it reaches to the optimal value and then increases with further increase in the $P_{\text {Cond }}$. The result shows that the optimal value for the $P_{\text {Cond }}$, at which the minimum production cost of electricity is achieved, is 0.045 bar.

Table 2 shows a comparison of the results between the initial case and optimised case of triple-pressure HRSG. The results show that the financial parameters are significantly better than the initial case. Thermoeconomic optimisation intend to achieve a trade-off between enhance the thermal efficiency of the power plant and economic parameters $\left(B, C_{K w h}\right)$.

Table 2. Comparison between the initial case and optimised case of triple-pressure HRSG CCGTs

\begin{tabular}{|c|c|c|c|}
\hline \multirow[b]{2}{*}{ Parameter } & \multirow[b]{2}{*}{$\begin{array}{l}\text { Initial } \\
\text { case }\end{array}$} & \multicolumn{2}{|c|}{ Optimised case } \\
\hline & & $\begin{array}{c}\text { Objective } \\
\text { function: Min. } \\
\text { Production } \\
\text { cost }\end{array}$ & $\begin{array}{c}\text { Objective } \\
\text { function: } \\
\text { Max. } \\
\text { Annual } \\
\text { cash flow } \\
\end{array}$ \\
\hline $\begin{array}{l}\text { Condenser } \\
\text { pressure } \\
\left(P_{\text {Cond. }}\right) \\
\end{array}$ & $0.057 \mathrm{bar}$ & 0.045 bar & 0.0445 bar \\
\hline $\begin{array}{l}\text { Heat transfer } \\
\text { area }\left(A_{\text {Cond. }}\right)\end{array}$ & $6838 \mathrm{~m}^{2}$ & $15201.9 \mathrm{~m}^{2}$ & $\begin{array}{c}16454.16 \\
\mathrm{~m}^{2}\end{array}$ \\
\hline $\begin{array}{l}\text { Combined } \\
\text { cycle- } \\
\text { efficiency } \\
\left(\eta_{\text {CCGT })}\right.\end{array}$ & $55.65 \%$ & $56.02 \%$ & $56.03 \%$ \\
\hline $\begin{array}{l}\text { Combined } \\
\text { cycle-gross } \\
\text { power } \\
\left(\mathrm{W}_{\mathrm{CCGT}}\right) \\
\end{array}$ & $\begin{array}{l}283.07 \\
\text { MW }\end{array}$ & $284.93 \mathrm{MW}$ & $285.02 \mathrm{MW}$ \\
\hline $\begin{array}{l}\text { Condenser } \\
\text { Cost }\left(C_{\text {Cond. }}\right) \\
\end{array}$ & $\begin{array}{l}\$ 2.091 \\
\text { million }\end{array}$ & $\$ 4.687$ million & $\begin{array}{l}\$ 5.077 \\
\text { million }\end{array}$ \\
\hline $\begin{array}{l}\text { Production } \\
\text { cost }\left(\mathrm{C}_{\mathrm{kWh}}\right)\end{array}$ & $\begin{array}{c}9.886 \\
\text { cent } / \mathrm{kWh}\end{array}$ & 9.843 cent $/ \mathrm{kWh}$ & - \\
\hline $\begin{array}{l}\text { Annual cash } \\
\text { flow (B ) }\end{array}$ & $\begin{array}{l}\$ 32.153 \\
\text { million }\end{array}$ & - & $\begin{array}{c}\$ 33.273 \\
\text { million }\end{array}$ \\
\hline
\end{tabular}

The results illustrates that the optimisation objectives function $\left(C_{k W h}\right.$ and $B$ ) led to different optimised parameter $P_{C o n d}$. Therefore, it is important to specify the thermoeconomic optimisation objective. In the case of a strong competition in liberalised electricity market and therefore it is difficult to sell the generated energy, the production costs per unit of electrical output $\left(C_{k W h}\right)$ optimisation should be done. Otherwise, in a regulated market with fixed energy prices where it is easy to sell the energy, the annual cash flow ( $B$ ) optimisation is better because this way more incomes are got due to the higher power reached.

In our case study triple-pressure HRSG combined cycle power plant, the efficiency of the selected combined cycle configuration could be increased by about $0.37 \%$ and the electrical output by more than $1.5 \mathrm{MW}$. On the other hand, the annual cash flow ( $B$ ) was increased by $\$ 1.1$ million by optimal selection of the condenser pressure. In addition, by selecting the optimal condenser pressure the production cost of electricity was decreased by 0.043 cent per kilowatt-hour.

\section{CONCLUSION}

In this paper, the thermoeconomic optimisation of a triplepressure HRSG for combined cycle power plants was investigated, and was applied on an example. The analysis indicated that the thermoeconmic optimisation procedure used in this study led to a significant improvement for the economic parameters. Compared with the initial case, the annual cash flow was increased by $\$ 1.1$ million, and the production cost of the electricity was decreased by 0.043 cent Kwh.

The results achieved here depend on many considerations such as the gas turbine selection, power plant configurations and the fuel price where the power plant was installed. The authors still work to investigate the effect of using all the operating parameters for the steam condenser to study both the thermodynamic and thermoeconmic optimisation for triple-pressure HRSG combined cycle power plant.

\section{REFERENCES}

[1] Alus, M., 2014, "New Method for Thermoeconomic Optimisation of Parameters of Triple-Pressure Combined Cycle Power Plants", Ph.D. thesis, University of Belgrade.

[2] Lakovic', M. S., Mitrovic', D. D., 2010, "Impact of the Cold End Operating Conditions on Energy Efficiency of the Steam Power Plants", Thermal Science, vol. 14 no. 1 , pp. 553-566.

[3] Wagner, W., Kruse, A., 1998, "Properties of Water and Steam", IAPWS-IF97, Springer, Berlin.

[4] Haldkar, V., Sharma, A. K., Ranjan, R. K. and Bajpai, V. K., 2013, "Parametric Analysis of Surface Condenser for thermal Power Plant", International Journal of Thermal Technologies, vol. 3, no. 4, pp. 155159.

[5] Ozdamar, G., Ozturk, R., 2012, "Optimisation of A condenser in A thermal Power Plant", 9th International Conference on Heat Transfer, Fluid Mechanics and Thermodynamics.

[6] Behr, H. D., Diederichsen, C., 1988, "Calculation equations for enthalpy and entropy of the components of air and combustion gases", BWK, vol. 40, no. 1-2, pp. 30-33.

[7] Li, W., Priddy, P., 1985, "Power Plant System Design", John Wiley \& Sons, Canada.

[8] Roosen, P., Uhlenbruck, S. and Lucas, K., 2003, "Pareto optimisation of a combined cycle power system as a decision support tool for trading off investment vs. operating costs", International Journal of Thermal Sciences, vol. 42, p. 553-560.

[9] Behbahani-nia, A., Sayadi, S. and Soleymani, M., 2010, "Thermoeconomic optimisation of the pinch point and gas-side velocity in heat recovery steam generators", Journal of Power and Energy, vol. 224, pp. 761-771.

[10] Silveira, J., Tuna, C., 2003, "Thermoeconomic analysis method for optimisation of combined heat and power systems, Part I", Progress in Energy and combustion Science, vol.29, pp. 479-485.

[11] Attala, L., Facchini, B. and Ferrara, G., 2001, "Thermoeconomic optimisation method as design tool in gas-steam combined plant realization", Energy Conversion and Management, vol. 42, pp. 2163-2172.

[12] Valdes, M., Duran, and Rovira, A., 2003, "Thermoeconomic optimisation of combined cycle gas turbine power plants using genetic algorithms", Applied Thermal Engineering, vol. 23, pp.2169-2182. 
International Journal of Science and Engineering Applications

Volume 6 Issue 03, 2017, ISSN-2319-7560 (Online)

[13] Manuel, V., Rovira A. and Durán, M. D., 2004, "Influence of the heat recovery steam generator design parameters on the thermoeconmic performance of combined cycle gas turbine power plants", International Journal Energy Research, vol. 28, pp. 1243-1254.

\section{Appendix}

\begin{tabular}{|c|c|c|c|}
\hline \multicolumn{4}{|c|}{ Nomenclature } \\
\hline$A$ & Heat transfer area $\left(\mathrm{m}^{2}\right)$ & $\eta$ & efficiency \\
\hline$c$ & Specific cost $(\$ / \mathrm{kWh})$ & $\mathrm{C}$ & Compressor \\
\hline$C$ & Cost $(\$)$ & $\mathrm{CC}$ & $\begin{array}{l}\text { Combustion } \\
\text { chamber }\end{array}$ \\
\hline$h$ & $\begin{array}{l}\text { Specific enthalpy } \\
(\mathrm{kJ} / \mathrm{kg})\end{array}$ & CCGT & $\begin{array}{l}\text { Combined cycle } \\
\text { power plant }\end{array}$ \\
\hline$h$ & $\begin{array}{l}\text { Number of operating } \\
\text { hours of the plant per } \\
\text { year }\end{array}$ & Cond. & Condenser \\
\hline$H_{l}$ & $\begin{array}{l}\text { Lower heat value of } \\
\text { fuel }(k J / k g)\end{array}$ & $\mathrm{f}$ & Fuel \\
\hline$I_{\text {tot }}$ & $\begin{array}{l}\text { Total income } \\
\text { (\$/year) }\end{array}$ & HRSG & $\begin{array}{l}\text { Heat recovery } \\
\text { steam generator }\end{array}$ \\
\hline$\dot{m}$ & Mass flow rate $(\mathrm{kg} / \mathrm{s})$ & HP & High pressure \\
\hline
\end{tabular}

\begin{tabular}{|c|l|c|l|}
\hline$N$ & $\begin{array}{l}\text { Economic life of the } \\
\text { plant (Year) }\end{array}$ & $\begin{array}{l}\text { Intermediate } \\
\text { pressure }\end{array}$ \\
\hline$k$ & $\begin{array}{l}\text { Specific cost of } \\
\text { components for HRSG } \\
(\$)\end{array}$ & LP & Low pressure \\
\hline$P$ & Pressure (bar) & $E$ & Economiser \\
\hline$\dot{Q}$ & Heat recovered ( kW) & $V$ & Evaporator \\
\hline$R$ & Additional cost factor & $S H$ & Superheater \\
\hline$S$ & $\begin{array}{l}\text { Selling price of } 1 \mathrm{kWh} \\
(\$ / \mathrm{kWh})\end{array}$ & $R E$ & Reheat \\
\hline$T$ & $\begin{array}{l}\text { Temperature } \\
\left(K \text { or }{ }^{o} C\right)\end{array}$ & $S T$ & Steam turbine \\
\hline$W$ & Power $(M W)$ & & \\
\hline
\end{tabular}

